\title{
TUBERCULOSIS IN PATIENTS WITH CHRONIC RENAL FAILURE
}

\author{
Flavio Jota de PAULA, lulz Sérgio Fonseca de AZEVEDO, Luiz Estevam LANHEZ, João Egidio \\ ROMAO JUNIOR, Redro Renato GHOGaIr \& Emil SABBaga
}

\section{S U M M A R Y}

Nine cases of tuberculosis (TB) were diagnosed among 800 uremic patients, followed-up during 11 years, a prevalence of $1.125 \%, 2.5$ times higher than that in the general population. Six patients $(66.7 \%)$ had lymph node involvement (4 cervical and 2 mediastinal). Three patients $(33.3 \%)$ had pulmonary involvement (2 pleuro-pulmonary and 1 bilateral apical pulmonary). Eight patients were undergoing dialysis and 1 was pre-dialytic. The duration of dialysis ranged from 1 to 60 months. Three patients had previously received immunosuppressive drugs for un. successful renal transplantation. Daily fever was present in all but one patient; he was asymptomatic and TB was suspected after routine chest radiography. Biopsy was the diagnostic procedure in 7 patients $(77.8 \%$ ), four by direct cervical lymph node biopsy, 2 by mediastinal, performed by mediastinoscopy and 1 by pleural biopsy. In 2 other patients $T B$ was confirmed by the presence of tubercle bacilli; in sputum (1 patient) and in a bronchial flushing specimen (the other patient). Triple therapy was used in all patients (isoniazid and ethambutol in all), plus rifampicin in 8 and streptomycin in 1. One patient had jaundice and another had optical neuritis. Five patients were cured. The other four died during treatment of causes unrelated to TB or its treatment.

KEY WORDS: Tuberculosis; Chronic renal failure; Dialysis

\section{N T ROD U G T I O N}

There has been an increasing number of publications concerning tuberculosis (TB) in pa. tients with chronic renal failure 1,2,6,9-11.

We describe here the clinical data of 9 uremic patients with TB.

\section{PATIENTS AND METHODS}

During a period of 11 years in which we followed up 800 patients with chronic renal failure, TB was diagnosed in 9 of them. The clinical data and sites of the tuberculous infection are summarized in Table $I$,

Fight patients were undergoing dialysis (7 haemodialysis and 1 peritoneal dialysis) and 1 was in the pre-dialytic phase. The duration of dialytic treatment ranged from 1 to 60 months (average of 17.33 months). Five patients were male. Ages ranged from 5 to 56 years (average of $26.5 \mathrm{yrs}$ ). Five were white, 2 were mullatoes and 1 was black. Three patients had received immunosuppressive drugs for unsuccessful renal transplants, 6 months (patients N.os 2 and $7)$ and 11 days (patient $N^{\circ} 6$ ) before the diagnosis of TB was established. No patient had received anti-tuberculous drugs prior to the diagnosis. None of them had epidemiological history of TB.

Daily persistent fever was present and was the most consistent complaint in all but one patient. This patient ( $\mathrm{N}^{\circ} 9$ ) was totally asymptomatic and TMB was diagnosed after a routine

From Unidade de Transplante Renal, Hospital das Clinicas, Faculdade de Medicina da Universidade de Săo Paulo. Caixa Postal 8091. CEP 01000 Ș̄o Paulo, SP, Brasill. 
PAULA, F. J. de; AZEVEDO, L. S. F. de; IANHEZ, L. E.; ROMAO JUNYOR, J. E.; CHOCAIR, P. R. \& SABBAGA, E. - Tuberculosis in patients with chronic renal failure. Rev. Inst. Med. trop. São Paulo, 29:127-130, 1987.

T A B L E I

General clinical data

\begin{tabular}{|c|c|c|c|c|c|}
\hline Patients & Age & Sex & 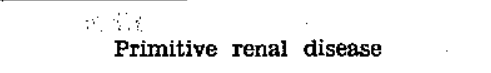 & treatment & $\begin{array}{l}\text { Site of tuberculous } \\
\text { infection }\end{array}$ \\
\hline 1 & $\mathbf{5}$ & $\mathrm{M}$ & Rapidly progressive glomerulonephritis & $\mathrm{PD} / 2 \mathrm{Mo}$ & Lymphonodular \\
\hline $\mathbf{2}^{*}$ & 20 & $\mathbf{F}$ & Interstitial nephropathy & $\mathrm{HD} / 5$ yrs & Lymphonodular \\
\hline 3 & 13 & $\mathbf{F}$ & Chronic glomerulonephritis & $\mathrm{HD} / 6 \mathrm{mo}$ & Lymphonodular \\
\hline 4 & 21 & $\mathrm{M}$ & Reflux glomerulopathy & $\mathrm{HD} / 2 \mathrm{mo}$ & Pleuro-pulmonary \\
\hline 5 & 46 & $\mathrm{~F}$ & Malignant nephrosclorosis & None & Lymphonodular \\
\hline 6* & 28 & M & Chronic glomerulonephritis & $\mathrm{HD} / 1$ mo & Lymphonodular \\
\hline $7^{*}$ & 28 & M & Diabetic nephropathy & $\mathrm{HO} / 2 \mathrm{mo}$ & Lymphonodular \\
\hline 8 & 43 & $\mathbf{F}$ & Chronic glomerulonephritis & $\mathrm{HD} / 2$ yrs & Pleuro-pulmonary \\
\hline 9 & 35 & $\mathrm{M}$ & Trauma in a single kidney & $\mathrm{HD} / 4 \mathrm{yrs}$ & Pulmonary \\
\hline
\end{tabular}

- Prior use of immunosuppressive therapy ( $6 \mathrm{mo}, 11$ days, $6 \mathrm{mo}$, respectively)

PD - peritoneal dialysis

HD $\rightarrow$ haemodialysis

abnormal chest radiography. Cervical lymph node enlargement was present in 4 patients $(44.4 \%)$ (Nos. 2, 5, 6 and 7). General symptoms such as asthenia, anorexia, weight loss and general malaise were also present in variable fre. quencies.

In those patients whose cervical lymph nodes were not enlarged, chest radiography was the first abnormal finding (patients N.:S 1, 3, 4, 8 and 9). In patients N.os 1 and 3, there was mediastinal enlargement. Tomography confirm. ed these findings and disclosed hilar lymph node enlargement in patient N. 1 . In patients $N$. 4 and 8 there were pulmonary lesions with pleural effusion (encapsulated in case N. 4). In patient $N .9$ there were infiltrating lesions with calcified nodules in both pulmonary apices.
Tuberculin test (PPD) was positive only in 1 case (patient N.O 3).

The diagnosis of TB was confirmed by biopsy in 7 patients $(77.8 \%)$. In 4 , this was by cervical lymph node biopsy; in 2 by mediastinal lymph node biopsy performed by mediastinoscopy; and in 1 by pleural biopsy. The histolo. gical examination of all biopsies disclosed the characteristic epithelioid granulomata with caseation necrosis. In 2 other patients the diagnosis was confirmed by the presence of tubercle bacilli in the sputum (patient N.. 9) and in the bronchial flushing specimen (patient N.: 4), either on direct microscopy or by culture in specific media (Table II). Thus the localization of TB was lymphatic in 6 patients $(66.7 \%)$ and pulmonary in $3(33.3 \%)$.

T́ A B I E II

Diagnostic methods

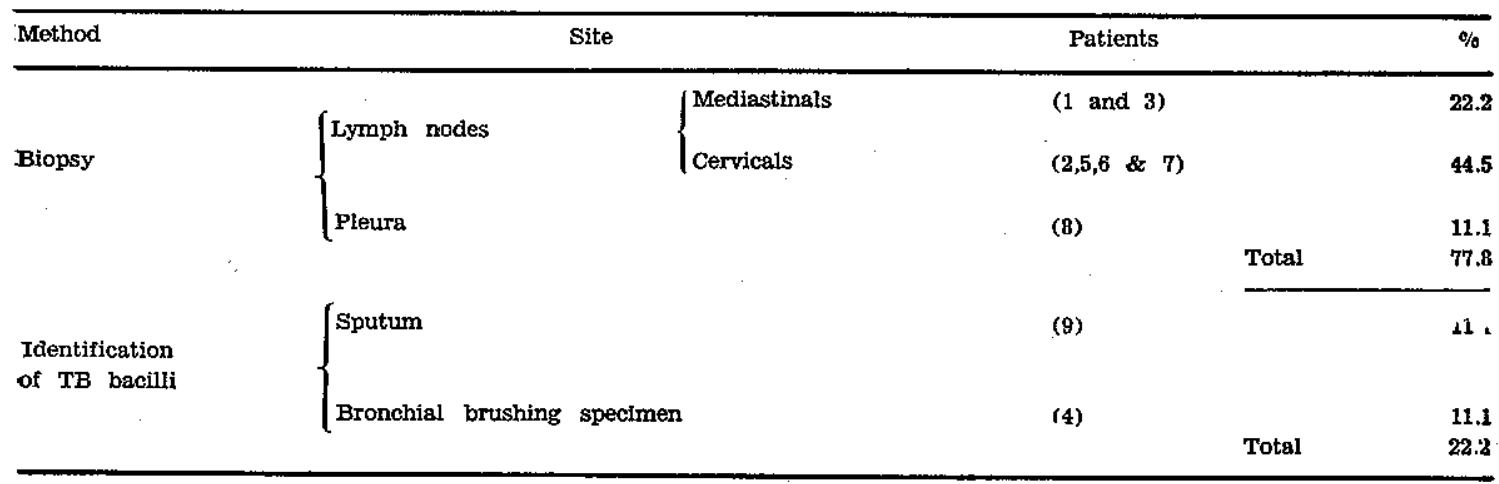

Tripletherapy was used in all patients: iso. niazid and ethambutol in all plus rifampicin in 8 and streptomycin in 1 . In all patients the doses of the drugs were reduced (the mean daily doses were: isoniazid $260 \mathrm{mg}$, ethambutol $460 \mathrm{mg}$, rifampicin $470 \mathrm{mg}$ and streptomiycin 0.5 
PAULA, F. J. de; AZEVEDO, L. S. F. de; IANHEZ, L. E.; ROMĀO JUNIOR, J. E.; CHOCAIR, P. R. \& SABBAGA, F.

- Tuberculosis in patients with chronic renal failure. Rev. Inst. Med. trop. São Paulo, 29:127-130, 1987.

mg). Side effects occurred in 2 patients: jaundice on the 13th day of treatment in patient N. 3 and optical neuritis on the 4 th month of treatment in patient $N .^{\circ} 6$.

Five patients were cured. Four died during the course of treatment (N.S 1, 3, 4 and 5). None of the deaths was a direct consequence of TB or its therapy.

\section{DISCUSSION}

TB in uremic patients occurs more frequently than in the general population. This greater prevalence could be explained by the impaired immunological response, both humoral and cellular, found in patients with chronic renal failure 3,4,12. Malnutrition, which can be present in these patients and the use of immunosup. pressive drugs (as was the case in 3 of our patients) could also be predisposing factors. The high prevalence of TB in under-developed areas is an added risk factor.

The $1.125 \%$ incidence of TB found among our patients is similar to that found elsewhe re 6,11. However, we found that the frequency of TB in our patients was 2.5 times higher than in that of the general Brazilian population, in contrast to the frequency of TB among uremic patients cited in the international literature, which is 10 to 15 times higher than that of the general population $1,2,6,9-11$. This finding could be explained by the fact that TB is still an endemic disease in Brazil.

A striking fact of clinical relevance was the predominance of lymphatic involvement (in two thirds of all cases) contrasting to the classical natural history of TB. This shows a pre. dominantly pleuro-pulmonary involvement. The lymphatic involvement is also in contrast to our findings in one study of 25 renal transplant patients with TB $^{8}$ in which the pulmonary form of TB predominated $(76 \%)$ with only one case of lymph node involvement ( $4 \%$ ). We could not find a reason for this unexpected frequency of lymph node involvement. Other authors also reported extrapulmonary forms as the most frequent $1,6,10$.

The time of emergence of $\mathrm{TB}$ during the dialysis period had so wide a range ( 1 to 60 months) that this points to the urgent need of investigating $\mathrm{TB}$ in all uremic patients with an unexplained fever. Our findings are in contrast to those of ANDREW et al. ${ }^{1}$ whose patients had $T B$ soon after starting dialysis.

A biopsy of the affected organ proved to be an extremely useful method in making early diagnosis of TB allowing the immediate start of therapy. In our experience this procedure proved to be harmless. We emphasize the use of biopsy, since the finding of tubercle bacilli occurs only in cases of pulmonary involvement and since its culture takes weeks to give a positive result. Making an early diagnosis with the immediate start of therapy are essential factors affecting the progress of patients.

As expected, the PPD test was useless as a diagnostic procedure. It is well known that uremia leads to an impaired cellular immunity.

Triple therapy was effective. It can be almost free of side effects if the dosages are adjusted not only to the levels of renal function, but also to the presence of hepatopathy. Liver damage can be common in uremic patients? A careful analysis of the patient prior to the start of therapy and a close follow-up can avoid the need of costiy monitoring of drug serum levels. The use of a relatively high dose of etham. butol $(600 \mathrm{mg} /$ day) for a prolonged period (4 months) was probably the cause of optical neuritis found in patient $N .^{\circ} 6$. Ethambutol in high doses is known as a cause of optical neuritis ${ }^{5}$. The severe jaundice found in patient N.० 3 was probably due to the use of rifampicin. Uremic patients may be more sensitive to side effects of this drug ${ }^{3}$. An underlying subclinical hepatopathy might also be a predisposing factor.

In conclusion TB can be a complication among uremic patients. Lymph node involve. ment responded in $66.7 \%$ of all clinical forms. TB should be searched for in all patients with chronic renal failure with unexplained fever. Early diagnosis and therapy with adequate doses of the drugs can give good results.

\section{RESUMO}

\section{Tuberculose em pacientes renais crônicos terminais}

Nove casos de tuberculose (TBC) foram diagnosticados entre 800 pacientes urêmicos acompanhados durante um periodo de 11 anos. 
PAULA, F. J. de; AZEVEDO, L. S. F. de; IANHEZ, L.' E.; ROMAOO JUNIOR, J. E.; CHOCAIR, P. R. \& SABBAGA, E - Tuberculosis in patients with chronic renal failure, Rev. Inst. Mej̄. trop. São Paulo, 29:127-130, 1987.

Isto constituiu uma prevalência de $1,125 \%, 2,5$ vezes maior que aquela da população geral. Seis pacientes $(66,7 \%)$ tiveram comprometimento dos linfonodos ( 4 cervicais e 2 mediastinais). Três pacientes $(33,3 \%)$ tiveram acometimento pulmonar (2, pleuro-pulmonar e 1, apical). Oito pacientes estavam em diálise e 1 estava na fase pré-dialítica. A duração do tratamento dialítico variou de 1 a 60 meses. Três pacientes receberam imunossupressão previamente por transplante renal mal sucedido. Febre diária esteve presente em todos pacientes, menos em um que era assintomático e cuja TBC foi suspeitada após uma radiografia de tórax rotineira anormal. Biópsia foi o procedimento diagnóstico em 7 pacientes $(77,8 \%)$. Quatro foram biópsias diretas de linfonodos cervicais, 2 de linfonodos mediastinais realizadas através de mediastinoscopia e uma da pleura. Em 2 outros pacientes a TBC foi confirmada pela presença do bacilo da tuberculose; em 1 caso no escarro e em outro no lavado brônquico. Esquema tríplice foi empregado em todos os casos (isoniazida e etam. butol em todos mais rifampicina em 8 e estreptomicina em 1). Um paciente teve icterícia e outro neurite optica. Cinco pacientes se curaram. Os outros 4 faleceram durante o trata mento por causas não relacionadas à TBC ou seu tratamento.

\section{REFERENCES}

1. ANDREW, O. T.; SCHOENFELD, P. Y.; HOPEWELL, P. C. \& HUMPHREYS, M. H. - Tuberculosis in pqtiens with end-stage renal disease. Amer. J. Med., 68: $59-65,1980$.

2. BELCON, M. C.; SMITH, E. K. M.; RAFANA, L. M. \& SHIMIZU, A. G. - Tuberculosis in dialysis patients. Clin. Nephrol., 17: 14-18, 1982.
3. BOULTON-JONES, J. M.; VICK, R.; CAMERON, J. S. \& BLACK, P. J. - Imune responses in uremia. Clin. Nephrol., 1: 351-360, 1973.

4. CHOCAIR, P. R.; CROCE, J. \& SABBAGA, E. - Verificaçăo da sensibilidado tardia na uremia. Rev. Ass. méd. bras., 17: 283-284, 1971.

5. GOODMAN, L. S. \& GIIMAN, A. - The pharmacological basis of therapeutics. New York, Macmillan Pus. blishing, 1975. p. 1209.

6. LUNDIN, A. A. \& BERLIXNE, G. A. - Tuberculosis in patients undergoing maintenance hemodialysis. Amer. J. Med., 67: 597-602, 1979.

7. OLIVEIRA, O. S.; MASSCLA, V. C.; IANHEZ, L. E.; SAIDANHA, L. B. \& SABBAGA, E. - Hepatopatias em pacientes com insuficiência renal crônica $\theta$ pós transplante renal. Rev. Ass. méd. bras., 22: 424-428, 1976.

8. PAULA, F. J.; IANHEZ, L. E.; AZEVEDO, L, S. F.; SALDANHA, L. B.; CHOCAIR, P. R. \& SABBAGA, E. - Tuberculose pós-transplante renal. In: CONGRESSO BRASTLEIRO DE NEFROLOGIA, 10., Fortaleza, 1980. Resumos. J. bras. Netrol., 3: 25, 1981.

9. PRADHAN, R. P.; KATZ, L. A.; NIDUS, B. D.; MA. TALON, R. \& EISINGER, R. P. - Tuberculosis in dialized patients. J. Amer. med. Ass., 229: 798-800, 1974.

10. RUTSKY, E. A. \& ROSTAND, S. G. - Mycobacteriosis in patients with chronic renal failure. Arch. intern. Med., 140: 57-61, 1980.

11. SASAKI, S.; AKIBA, T.; SUUEAGA, M.; TOMURA, S.; YOSHIYAMA, N.; NAKAGAWA, S.; SHOJ, T.; SA. SAOKA, T. \& TAKEUCHI, J. - Ten years' survey of dialysis-associated tuberculosis. Nephron, 24: 141-145 1979.

12. WILSON, W. E. C.; KIRKXPATRICK, C. H. \& TAL MAGE, D. W. - Suppression of immunologic responsi veness in uremia. Ann. intern. Mex., 6\%: 1-14, 1965.

Recebido para publicaçäo em 14/3/86. 